\title{
The Usefulness Of The Tax Avoidance Proxy: Evidence From Korea
}

\author{
Hyun-Ah Lee, Gachon University, South Korea
}

\begin{abstract}
This study aims to verify the usefulness of the tax avoidance proxy developed by Desai and Dharmapala (2006) in the setting where accounting-tax alignment is relatively high and aggressive tax planning is restricted. By using a large set of firms in Korea, I empirically test whether the tax avoidance proxy detects the management of book-tax and book-only accruals. My findings show that downward management of book-tax accruals for tax reporting purposes is not detected by the tax avoidance proxy. However, upward management of book-only accruals for financial reporting purposes is captured by the tax avoidance proxy. In addition, the tax avoidance proxy better detects simultaneous management of two accrual components than management of book-tax accruals alone. Lastly, the tax avoidance proxy is more powerful in detecting tax avoidance activities in a sample of firms with high tax and financial reporting costs than in firms that carry high tax costs but low financial reporting costs. The results of this study imply that the tax avoidance proxy can be a good indicator only when used for firms that are conscious of their financial reporting costs and have incentive to manage both taxable and book income at the same time under the setting where book-tax conformity is high and aggressive tax shelters are restricted. This study sheds light on the usefulness of the tax avoidance proxy which has been widely used in the accounting studies and provides a caveat to researchers that the proxy should be employed with caution and in appropriate setting.
\end{abstract}

Keywords: Tax Avoidance; Earnings Management; Book-Tax Accruals; Book-Only Accruals

\section{INTRODUCTION}

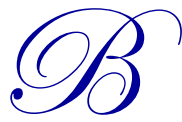

ook income based on accounting standards is the most widely used summary measure of a firm's financial performance by market participants in debt covenants, compensation contracts, and stock market pricing. Taxable income, as determined by tax rules, is used to calculate the amount of taxes to be paid to the tax authorities. Therefore, firms have two incentives: to report higher book income for financial reporting purposes and to report lower taxable income for tax reporting purposes. When firms report increased book income and/or decreased taxable income, the difference between them becomes evident. A large body of literature from the U.S. has provided evidence that the book-tax difference reflects earnings management and/or tax avoidance (Lev and Nissim 2004; Phillips et al. 2003; Hanlon 2005; Mills 1998; Manzon and Plesko 2002; Desai 2003). Based on the results of these studies, Desai and Dharmapala (2006) develop a proxy of tax avoidance measured by the residual of the book-tax difference that cannot be explained by earnings management.

The proxy developed by Desai and Dharmapala (2006) is widely used in the literature on tax avoidance in the other countries as well as in the U.S. However, the tax avoidance proxy should be employed with caution and in the appropriate setting because the results of studies that investigate the association between the book-tax difference and tax avoidance are not consistent in countries outside of the U.S. For example, in Korea, Shim et al. (2006) find no evidence that a higher book-tax difference increases the probability of tax audit and higher penalty taxes, while Choi (2012) finds a positive relationship between the book-tax difference and penalty taxes as a result of tax investigation. These inconsistent results may be caused by the unique accounting and tax environment in Korea, where accounting-tax alignment is relatively high and aggressive tax planning is restricted. Relatively high accounting-tax alignment results from differences in treatment of allowances and the depreciation in accounting standards and tax laws. In Korea, allowances for uncollectible accounts or pensions are tax deductible as long as they are within the limit specified by the tax rules; conversely, they are not tax deductible in the U.S. Many U.S. firms use straight line depreciation for book purposes and accelerated depreciation for tax purposes, but Korean firms usually use the same depreciation methods and useful life measures for both book and tax purposes (Choi et al. 
2009). In addition, aggressive tax planning by multinational firms through tax havens or transfer pricing is less common in Korea than in the U.S. (Choi and Lee 2013).

In this environment, items with high book-tax conformity are the only opportunistic and primary tools for firms to avoid paying taxes. For example, firms may manage the accruals with high book-tax conformity ("book-tax accruals", hereafter) downward in an attempt to reduce taxable income. ${ }^{1}$ However, downward management of booktax accruals affects both book income and taxable income negatively. Thus, firms may adjust accruals with low book-tax conformity ("book-only accruals", hereafter) upward to compensate for the increased financial reporting costs without affecting taxable income (Calegari 2000). ${ }^{2}$

In cases where book-tax accruals are primarily used for tax reporting purposes, the proxy developed by Desai and Dharmapala (2006) ("tax avoidance proxy", hereafter) may not be a good indicator of tax avoidance because it is not expected to detect tax avoidance activities that do not affect the gap between book and taxable income. On the other hand, if firms use book-only accruals to compensate for the reduction in book income due to management of booktax accruals, the tax avoidance proxy may detect upward management of book-only accruals, which generates a book-tax difference. However, management of book-only accruals may not be captured by the tax avoidance proxy because book-only accruals is a component of total accruals, and total accruals is excluded from the book-tax difference in computation of the tax avoidance proxy. This empirical question as to whether the tax avoidance proxy captures accruals management requires investigation. Therefore, I test the ability of the proxy to detect management of book-tax and book-only accruals. I also test whether the tax avoidance proxy better detects the simultaneous management of the two accrual components (downward management of book-tax accruals and upward management of book-only accruals) than management of book-tax accruals alone. In addition, firms have incentives to manage both accrual components at the same time when both financial reporting costs and tax costs are high. Thus, I examine whether the proxy is more powerful in detecting tax avoidance activities in a sample of firms with high tax and financial reporting costs than in firms that carry high tax costs, but low financial reporting costs.

To test my hypotheses, I investigate a large set of firms listed on the Korea Stock Exchange during the period between 2000 and 2013. My findings show that the tax avoidance proxy does not capture downward management of book-tax accruals; however, it is positively associated with upward management of book-only accruals. This implies that the tax avoidance proxy is not suitable for firms that cannot opportunistically use tax planning resulting in a book-tax difference. In addition, they provide the evidence that the tax avoidance proxy cannot exclude the effect of earnings management via book-only accruals.

I also find that the tax avoidance proxy better detects simultaneous management of the two accrual components than management of book-tax accruals alone. In addition, by assessing the firm's tax and financial reporting costs using the previous year's taxable income and debt ratio, respectively, I find that firms with high tax and financial reporting costs show higher levels of tax avoidance than firms with high tax costs and low financial reporting costs. These results imply that the proxy can still be effective in measuring tax avoidance in firms that have concerns about increased financial reporting costs due to tax avoidance activities.

The results of this study provide additional insight into previous findings in tax avoidance and earnings management research. First, this study sheds light on the usefulness of the tax avoidance proxy developed by Desai and Dharmapala (2006) in the distinctive setting where book-tax conformity is high and aggressive tax planning is restricted. The findings provide a caveat to researchers that the level of tax avoidance can be erroneously measured by the employment of the proxy without considering the distinctive characteristics of the accounting and tax environment. Second, the management of book-only accruals, which can be considered as earnings management, should not be overlooked when investigating tax avoidance activities. Lastly, more attention should be paid to tax avoidance activities that do not result in a book-tax difference when analyzing firms with high book-tax conformity.

\footnotetext{
${ }^{1}$ For example, in many cases, as tax provisions for revenue and expense recognition are similar to those for financial reporting, revenue and expenses are recognized in the same period for both tax and financial reporting purposes. These similarities allow managers to reduce taxable income by either reducing revenue accruals or increasing expense accruals.

${ }_{2}^{2}$ As tax provisions and financial reporting requirements differ in their treatment of allowance for bad debts and depreciation, managers may attempt to increase book income only by reducing the allowance for uncollectible accounts or depreciation, leaving taxable income unchanged.
} 
I believe that the results of this study are meaningful not only for researchers, but also for users of financial information, auditors, and regulators who are interested in tax avoidance activity.

The rest of the paper proceeds as follows. Section 2 describes previous research in this area and lays out the hypotheses. Section 3 outlines the research method and the model used to prove the hypotheses. Empirical evidence is provided in Section 4. In section 5, I summarize and conclude.

\section{PREVIOUS RESEARCH AND HYPOTHESES DEVELOPMENT}

\subsection{Previous Research}

The book-tax difference has been extensively examined by various researchers. The literature can be classified into two categories. Many studies attempt to explain the book-tax difference by focusing on earnings management or earnings quality. Other studies attempt to explain the book-tax difference by focusing on tax avoidance. Lev and Nissim (2004) investigate the relation between the ratio of taxable to book income and future earnings growth and show that a higher book-tax difference is related to lower future earnings growth because the book-tax difference reflects earnings management activities that are not persistent. Hanlon (2005) also finds that firms with large positive book-tax differences have lower earnings persistence than firms with small book-tax differences. He also finds that investors interpret large book-tax differences as a bad sign (referred to as a "red flag" in his study), reducing their expectations of future earnings persistence accordingly.

On the other hand, Mills (1998) shows that a large book-tax difference increases the likelihood of IRS audit and adjustment. He finds a correlation between the book-tax difference and tax avoidance. Manzon and Plesko (2002) also report that a few measures approximating the demand for tax shelters help explain the book-tax difference. Desai (2003) also provides evidence that the book-tax difference is related to tax avoidance. He traces the growing the book-tax difference associated with differential treatments of depreciation and other factors. He finds that more than half of book-tax difference cannot be accounted for by those factors.

Based on the results of the above studies, Desai and Dharmapala (2006) develop a measure of tax avoidance by controlling for the component attributable to earnings management activity. They regress the book-tax difference on total accruals by assuming that any difference not explained by earnings management can be interpreted as a measure of tax avoidance. They interpret the residual book-tax difference as a more precise measure of tax sheltering activity; this method has been widely used in studies of tax avoidance.

On the other hand, some studies investigate tax avoidance by focusing on accounting choices that do not lead to a book-tax difference. Jenkins and Pincus (1998) find that firms adopt a LIFO strategy in inventory accounting in order to save on taxes. Scholes and Wolfson (1992) investigate whether firms shift income across time periods in response to the United States Tax Reform Act of 1986 ("TRA 86", hereafter), which reduced the corporate tax rate from a maximum of $46 \%$ to $34 \%$ over a period of two years. They find that firms shift some portion of their gross margin from the preceding quarters to quarters of scheduled tax rate reduction to reduce taxes. Guenther (1994) focuses on discretionary accruals that are expected to affect taxable income. He finds reduced discretionary accruals in the year prior to the passage of TRA 86 in many firms.

Calegari (2000) extends the research of prior studies by dividing accruals into two different types depending on whether or not they affect taxable income. He defines accruals with high book-tax conformity as book-tax accruals and finds that firms with increased marginal tax rates due to TRA 86 adjust their book-tax accruals downward for tax avoidance purposes. In addition, he defines accruals with low book-tax conformity as book-only accruals and finds simultaneous adjustment of book-only accruals upward to accomplish financial reporting objectives. In Korea, Choi and Lee (2013) also divide accruals into two components, investigating adjustment of these two components in response to tax rate reductions. They find that firms manage book-tax accruals in order to shift taxable income and manage book-only accruals in order to compensate for the commensurate reduction in book income in response to tax rate reductions. 
In sum, tax avoidance activities can be classified into two types - tax avoidance that causes book-tax differences and tax avoidance that does not. Although the proxy of Desai and Dharmapala (2006) was developed to measure the former type of tax avoidance activity, it has been widely used without discrimination between these two types. To the best of my knowledge, this is the first study to evaluate the usefulness of this tax avoidance proxy in the unique setting where firms are likely to avoid taxes without generating book-tax differences. This study aims to identify at what point the proxy becomes a more precise measure of tax avoidance.

\subsection{Hypotheses Development}

Book-tax differences in Korea are relatively lower than that of the U.S. Specifically, the average ratio of book income to taxable income in the U.S. is in the range of 1.4-1.7, while in Korea, it is in the range of 0.9-1.1 (Mills and Plesko 2003; Choi et al. 2009). The relatively lower book-tax difference in Korea is mostly due to differences in the treatment of allowances and the depreciation in accounting standards and tax laws. First, in Korea, allowances are tax deductible as long as they are within the limit specified by tax laws; by contrast, they are not tax deductible at all in the U.S. Second, many U.S. firms use straight line depreciation for book purposes and accelerated depreciation for tax purposes, but Korean firms usually use the same depreciation methods and useful life measures for both book and tax purposes. In addition, there are a less number of multinational firms that opportunistically utilize the aggressive tax planning through as tax havens or transfer pricing in Korea than in the U.S (Choi and Lee 2013).

Therefore, Korean firms that attempt to avoid paying taxes do not have many options; thus, they are highly likely to manage items with high book-tax conformity. Accruals with high book-tax conformity are the representative and primary tools for tax avoidance in Korea. However, managing book-tax accruals decreases book income as well as taxable income, not resulting in the gap between book and taxable income. Accordingly, the management of booktax accruals for tax planning may not be detected by the proxy developed by Desai and Dharmapala (2006), which measures tax sheltering activity by the residual of the book-tax difference that cannot be explained by earnings management.

When firms manage taxable income downward through book-tax accruals, they may also utilize book-only accruals to increase the book income, which is otherwise decreased along with taxable income. Strictly speaking, management of book-only accruals can be considered as earnings management, but it may be detected by tax avoidance proxy since it generates book-tax difference and is likely to be accompanied by tax avoidance. On the other hand, management of book-only accruals may not be captured by the tax avoidance proxy because the tax avoidance proxy is measured by disentangling total accruals from book-tax difference, and total accruals includes book-only accruals. Therefore, I am unable to ex ante predict a direction for the association between management of book-only accruals and tax avoidance proxy. To assess the usefulness of the tax avoidance proxy in detecting the management of these two accrual components empirically, the first hypothesis is therefore formulated as a null hypothesis.

Hypothesis 1: Downward management of book-tax accruals and upward management of book-only accruals are not detected by the tax avoidance proxy.

This first hypothesis is set to investigate empirically the relationship between the tax avoidance proxy and the management of book-tax and book-only accruals. However, the first hypothesis includes the cases where book-only accruals are managed solely for financial reporting purposes. Since the focus of this study is on the accrual management related to tax avoidance, the second hypothesis analyzes the usefulness of the tax avoidance proxy to detect management of book-only accruals simultaneously managed with book-tax accruals.

Cases of tax avoidance can be classified into two types. Firms that belong to the first type simultaneously manage book-tax accruals downward and manage book-only accruals upward. Other firms manage book-tax accruals only downward because they are unconcerned about reduced book income. In the first case, a book-tax difference is generated, while in the second case, it is not. Since the tax avoidance proxy is created by focusing on the book-tax difference, it may be more useful for detection of the former type of tax avoidance than the latter type. However, if management of book-only accruals is not captured by the tax avoidance proxy, it may not have the ability to 
distinguish these two types of tax avoidance. Ex ante prediction of the ability of the tax avoidance proxy to distinguish these types of tax avoidance is difficult; therefore, the second hypothesis is formulated as a null hypothesis as follows.

Hypothesis 2: The tax avoidance proxy does not distinguish between the simultaneous management of book-tax and book-only accruals and management of book-tax accruals alone.

The extent of management of book-tax and book-only accruals varies depending on the firm's tax and financial reporting costs. Firms burdened with high costs for both tax and financial reporting have incentive to manage booktax accruals downward to decrease tax costs while concurrently managing book-only accruals upward to decrease financial reporting costs. On the other hand, firms that have high tax costs but low financial reporting costs have less incentive to manage book-only accruals upward while managing book-tax accruals downward. In other words, the probability of engaging in simultaneous management of these two accrual components for tax planning purposes is higher for firms that belong to the former group than for firms in the other group. If the tax avoidance proxy is useful to detect the probability of book-only accruals management according to firms' financial reporting costs, the level of tax avoidance proxy would be higher for the former type of firms than the latter type of firms. However, if the tax avoidance proxy is independent from management of book-only accruals, it is likely that the tax avoidance proxy is unrelated to the incentive to manage book-only accruals. Therefore, the level of the tax avoidance proxy does not differ according to firms' financial reporting costs when their tax costs are high. Similar to hypotheses 1 and 2, the third hypothesis is therefore formulated as a null hypothesis as follows.

Hypothesis 3: The level of the tax avoidance proxy does not differ according to firms' financial reporting costs when their tax costs are high.

\section{RESEARCH METHOD AND SAMPLE SELECTION}

\subsection{Designing the Research Model}

\subsubsection{Book-Tax Accruals and Book-Only Accruals}

This study follows the approach of Calegari (2000) in calculating book-tax and book-only accruals. First, total current accruals for firm $i$ in year $t$ is calculated using the following equation.

$$
\begin{aligned}
& T C A_{i, t}=\left(\triangle C A_{i, t}-\triangle C A S H_{i, t}\right)-\left(\triangle C L_{i, t}-\triangle S T D_{i, t}\right)-D E P_{i, t} \\
& T C A_{i, t}: \text { Total current accruals; } \\
& \triangle C A_{i, t}: \text { Changes in current assets; } \\
& \triangle C A S H_{i, t}: \text { Changes in cash and cash equivalent; } \\
& \triangle C L_{i, t}: \text { Changes in current liabilities; } \\
& \triangle S T D_{i, t}: \text { Changes in long-term current liabilities; and } \\
& D E P_{i, t}: \text { Depreciation expenses for tangible and intangible assets. }
\end{aligned}
$$

(All variables above are scaled by total assets at the beginning of the year)

Second, total current accruals (TCA) can be divided into total book-tax accruals and total book-only accruals. Specifically, allowance for bad debts, allowance for inventory valuation loss, depreciation, and amortization expenses are classified as book-only accruals $(B O A)$ because they are treated differently by tax laws and accounting standards in Korea. Deferred tax assets/liability and tax receivable/payable are also classified as book-only accruals 
$(B O A)$ because they cannot be utilized to manage taxable income. Book-tax accruals $(B T A)$ are estimated by subtracting book-only accruals $(B O A)$ from total current accruals, as follows.

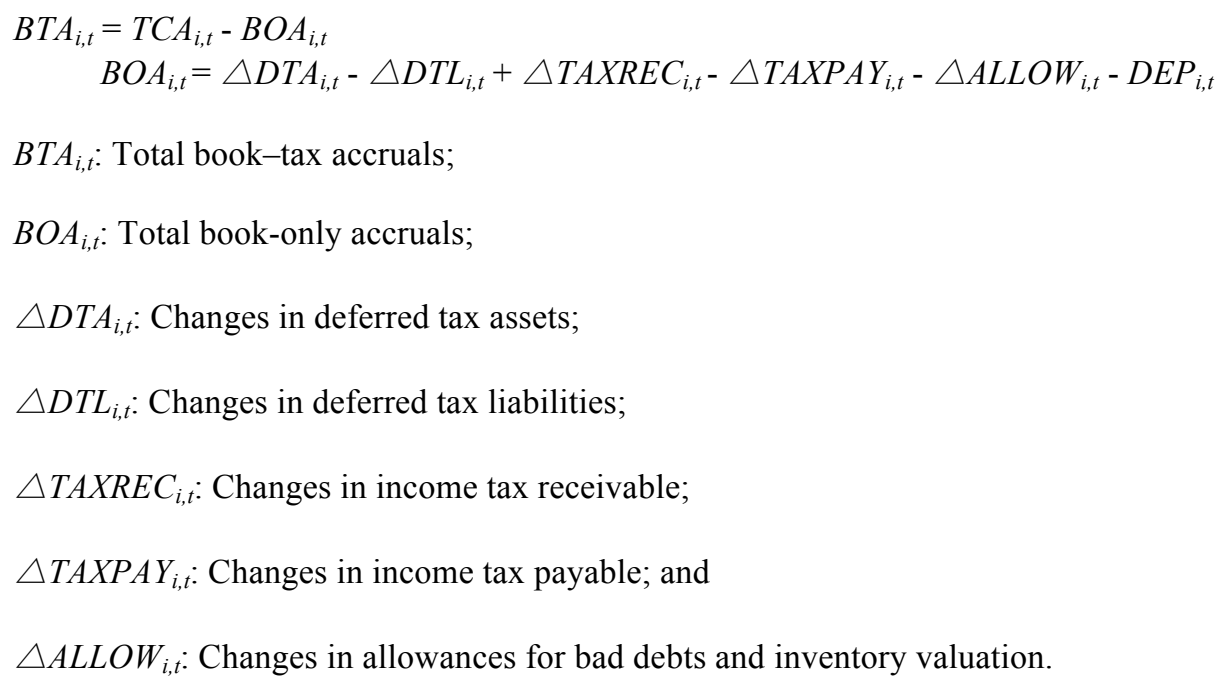

(All variables are scaled by total assets at the beginning of the year)

The third procedure is to distinguish the discretionary portions of book-tax accruals $(B T A)$ and book-only accruals $(B O A)$ by subtracting non-discretionary portions from total book-tax accruals and book-only accruals. Discretionary book-tax accruals $(D B T A)$ and discretionary book-only accruals $(D B O A)$ are determined as the residuals of the following equations, respectively.

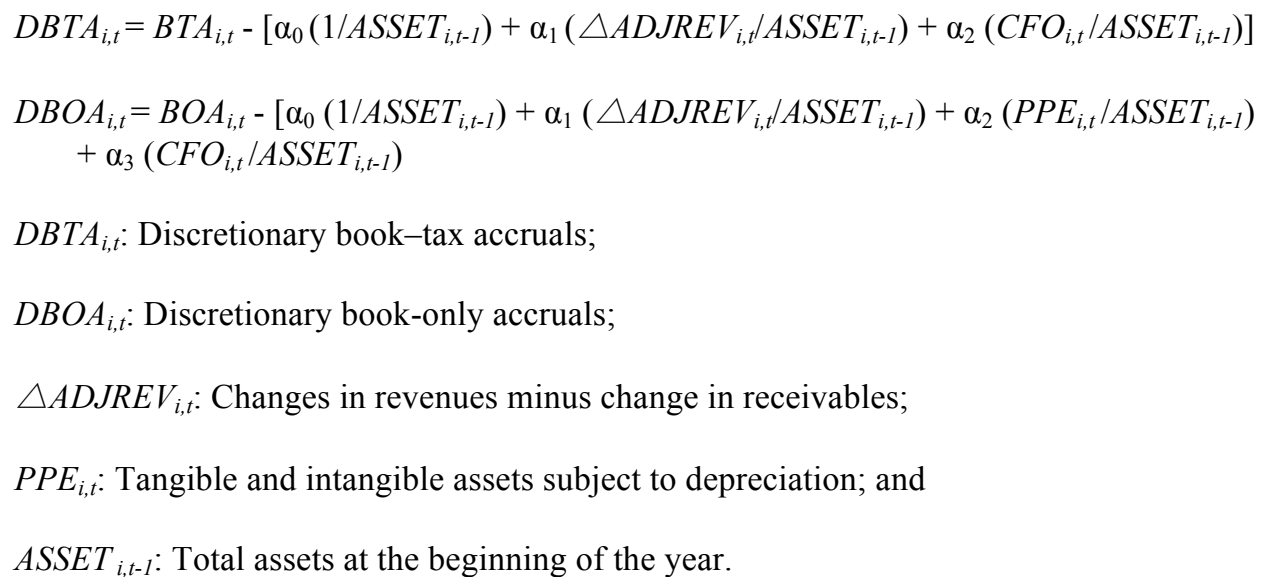

Lastly, changes in book-tax accruals ( $\triangle D B T A$ ) and book-only accruals ( $\triangle D B O A$ ) for firm $i$ in year $t$ are estimated by subtracting the values of year $t-1$ from the respective values of year $t$. The greater the adjustment of book-tax accruals to lower taxable income, the higher the negative value of $\triangle D B T A$. On the other hand, $\triangle D B O A$ will have a greater positive value commensurate with the adjustment of book-only accruals in order to manage the book income upward without affecting taxable income.

$$
\begin{aligned}
& \triangle D B T A_{i, t}=D B T A_{i, t}-D B T A_{i, t-1} \\
& \triangle D B O A_{i, t}=D B O A_{i, t}-D B O A_{i, t-1}
\end{aligned}
$$




\subsubsection{The Tax Avoidance Proxy}

Desai and Dharmapala (2006) develop a tax avoidance measure by regressing the total book-tax difference (BTD) on total accruals. As a result, the component of $B T D$, which cannot be captured by earnings management, is interpreted as a tax sheltering activity. The residual of the following equation is used to represent the level of tax avoidance in this study.

$$
\begin{aligned}
& B T D_{i, t}=T A_{i, t}+\varepsilon_{i, t} \\
& B T D_{i, t}: \text { Book-tax difference for firm } i \text { in year } t \text {, and } \\
& T A_{i, t} \text {. Total accruals for firm } i \text { in year } t .
\end{aligned}
$$

\subsection{Model Specifications}

I develop regression model (1) to test the relationships between the tax avoidance proxy and downward management of book-tax accruals and upward management of book-only accruals. The tax avoidance proxy (TAXAVOID) is a dependent variable and $\triangle D B T A$ and $\triangle D B O A$ are independent variables. Along with our variables of interest, we also include control variables that can influence a firm's tax avoidance. These factors include the firm size, leverage, profitability, cash flows, growth, and ownership structure.

The coefficient of $\triangle D B T A\left(\beta_{l}\right)$ is expected not to be statistically significant, as downward management of book-tax accruals does not affect the book-tax difference. By contrast, the coefficient of $\triangle D B O A\left(\beta_{2}\right)$ may be positive, as upward management of book-only accruals accompanies an increase in the book-tax difference. However, since the tax avoidance proxy is measured by the residual excluding the total accruals from the book-tax difference, $\beta_{2}$ may not be statistically significant if the tax avoidance proxy already controls for management of book-only accruals, which is a component of total accruals.

TAXAVOID $_{i, t}=\beta_{0}+\beta_{1} \triangle D B T A_{i, t}+\beta_{2} \triangle D B O A_{i, t}+\beta_{3} S_{S I Z E_{i, t}}+\beta_{4} L E V_{i, t}+\beta_{5} R O A_{i, t}+\beta_{6} C F O_{i, t}$

$+\beta_{7}$ GROWTH $_{i, t}+\beta_{8} M T B_{i, t}+\beta_{9} O W N_{i, t}+\beta_{10} F O R_{i, t}+\sum Y R+\sum I N D+\varepsilon$

TAXAVOID ${ }_{i, t}$ : Desai and Dharmapala (2006)'s tax avoidance proxy for firm $i$ in year $t$;

$S I Z E_{i, t}: \log$ of total assets;

$L E V_{i, t}:$ Total liabilities divided by total assets;

$R O A_{i, t}$ : Net income divided by total assets at the beginning of the year;

$C F O_{i, t}$ : Cash flows from operations divided by total assets at the beginning of the year;

GROWTH $_{i, t}$ : Change in sales divided by previous year's sales;

$M T B_{i, t}$ : Market value divided by equity;

$O W N_{i, t}$ : Proportion of ownership held by the largest shareholder of the firm;

$F O R_{i, t}$ : Proportion of ownership held by foreign investors of the firm;

$Y R$ : Year indicators; and

$I N D$ : Industry indicators. 
Regression model (2) is estimated to test the second hypothesis. To verify whether the tax avoidance proxy distinguishes between the simultaneous management of two accrual components and management of book-tax accruals alone, I deploy a dummy variable, $C O M P \_D$. The dummy variable is assigned a value of 1 if $\triangle D B T A$ is negative, while $\triangle D B O A$ is positive or 0 if both $\triangle D B T A$ and $\triangle D B O A$ show negative values. If the tax avoidance proxy better detects simultaneous management of the two accrual components than management of book-tax accruals alone, the coefficient of COMP_D $\left(\beta_{I}\right)$ will be positive. However, if the tax avoidance proxy does not distinguish between the simultaneous management of the two accrual components and management of book-tax accruals alone, the coefficient of COMP_D $\left(\beta_{I}\right)$ will not be statistically significant.

$$
\begin{array}{r}
\text { TAXAVOID } \\
+\beta_{i, t}=\beta_{0}+\beta_{1} \text { COMP }_{-} D_{i, t}+\beta_{2} \text { SIZE }_{i, t}+\beta_{3} L E V_{i, t}+\beta_{4} R O A_{i, t}+\beta_{5} C F O_{i, t} \\
+\beta_{6} \text { GROWTH }_{i, t}+\beta_{7} M T B_{i, t}+\beta_{8} O W N_{i, t}+\beta_{9} F O R_{i, t}+\sum Y R+\sum I N D+\varepsilon
\end{array}
$$

COMP_ $D_{i, t}$ : Dummy variable that equals 1 if $\triangle D B T A$ is negative and $\triangle D B O A$ is positive, and 0 if $\triangle D B T A$ and $\triangle D B O A$ are both negative.

I develop the following regression model (3) to test the third hypothesis. Firms generally manage book-tax accruals and book-only accruals concurrently when both tax and financial reporting costs are high. This study measures tax and financial reporting costs using taxable income and the debt ratio in the previous year, respectively. ${ }^{3}$ Since the current year's taxable income and debt ratio are already affected by the managers' accounting choices for tax planning, the values in the previous year are used as ex ante proxies of tax and financial reporting costs.

TAXFIN_D is a dummy variable which equals 1 if both the taxable income and debt ratio of the previous year are higher than those of the median, and 0 if they are lower than those of the median. ${ }^{4}$ Firms with high tax and financial reporting costs have more incentives to choose a tax planning strategy that will generate a higher book-tax difference than those with high tax costs only. Hence, if the tax avoidance proxy captures the probability of a tax planning strategy to increase the book-tax difference, the coefficient of TAXFIN_D $\left(\beta_{1}\right)$ is expected to have a positive value. However, the coefficient of TAXFIN_D $\left(\beta_{l}\right)$ may not be statistically significant if the tax avoidance proxy is not unrelated to a tax planning strategy that generates a book-tax difference.

$$
\begin{array}{r}
\text { TAXAVOID } \\
+\beta_{i, t}=\beta_{0}+\beta_{1} \text { TAXFIN_D }_{i, t}+\beta_{2} \text { SIZE }_{i, t}+\beta_{3} L E V_{i, t}+\beta_{4} R O A_{i, t}+\beta_{5} C F O_{i, t} \\
+\beta_{6} \text { GROWTH }_{i, t}+\beta_{7} M T B_{i, t}+\beta_{8} O W N_{i, t}+\beta_{9} F O R_{i, t}+\sum Y R+\sum I N D+\varepsilon
\end{array}
$$

TAXFIN_D $D_{i, t}$ : Dummy variable that equals 1 if scaled taxable income and leverage ratio in year $t-1$ are both higher than the median value, and 0 if scaled taxable income in year $t-1$ is higher than the median value, but debt ratio in year $t-1$ is lower than the median value.

\subsection{Sample Selection}

My initial sample consists of firms listed on the Korea Stock Exchange during the period between 2000 and 2013. Financial firms are excluded from the sample due to the unique nature of their financial data. Non-December yearend firms are also eliminated from the sample for homogeneity. Financial information, market value, and ownership data are gathered from the TS2000 (http://www.kokoinfo.com) and KIS-VALUE (http://www.kisline.com) databases. $^{5}$ I also eliminate firm-year observations less than 10 by industry and year because more than 10 observations are necessary to estimate the discretionary portion of book-tax and book-only accruals, using the modified Jones model. Next, I delete observations without $\triangle D B T A$ or $\triangle D B O A$. Lastly, I exclude firm-year observations whose market value, largest shareholder's ownership, or foreign investors' ownership is not available

\footnotetext{
${ }^{3}$ In this study, the financial reporting cost is measured using the debt ratio. The larger a firm's debt ratio, the more likely the firms' manager is to select income-increasing accounting strategies (Watts and Zimmerman 1986; Sweeney 1994). Firms with a high debt ratio have higher financial reporting costs, and thus are more likely to manage book income upward.

${ }_{5}^{4}$ The median used in this study is the value adjusted by year and industry.

${ }^{5}$ The TS2000 and KIS-VALUE systems are Korean equivalents of COMPUSTAT or CRSP in the U.S., providing financial and stock price data for firms listed on the Korea Stock Exchange (Choi and Lee 2013).
} 
in the databases. These procedures resulted in a final sample comprised of 5,894 firm-years. The procedure for the sample selection is presented in Table 1.

Table 1. Sample Selection Procedure

\begin{tabular}{l|c}
\hline \multicolumn{1}{c|}{ Procedure } & No. of Firm-Years \\
\hline $\begin{array}{l}\text { Observations from data in TS2000 and KIS-VALUE databases excluding firms in the } \\
\text { financial industry in years 2000-2013. }\end{array}$ & 8,136 \\
\hline Less: & 294 \\
\hline Non-December year-end firms & 161 \\
\hline Firm-year observations less than 10 by industry and year & 629 \\
\hline Observations without $\triangle D B T A$ or $\triangle D B O A$ & 1,158 \\
\hline $\begin{array}{l}\text { Observations whose market value, largest shareholder's ownership, or foreign } \\
\text { investors' ownership is not available }\end{array}$ & 5,894 \\
\hline Final firm-years sample & \\
\hline
\end{tabular}

\section{EMPIRICAL RESULTS}

\subsection{Descriptive Statistics}

Table 2 presents the descriptive statistics for the variables used in the tests. To rule out the effects of outliers, I winsorize the top and bottom $1 \%$ of each continuous variable. The tax avoidance measure (TAXAVOID) developed by Desai and Dharmapala (2006) has a mean (median) of $0.013(0.011)$, suggesting that firms tend to avoid their taxes on average.

The distributions of the values for $\triangle D B T A$ and $\triangle D B O A$ are symmetrical and their mean (median) values are close to zero. The range for $\triangle D B T A$ is wider than the range for $\triangle D B O A$ because book-only accruals are limited to accounts with low book-tax conformity such as allowances. $C O M P_{-} D$ has a mean value of 0.556 , indicating that the percentage of firms with negative $\triangle D B T A$ and positive $\triangle D B \bar{O} A$ is about $56 \%$ of the sample $(\mathrm{n}=2,947)$. TAXFIN_D has a mean value of 0.386 , indicating that the percentage of firms with high tax and financial reporting costs simultaneously is about $38.6 \%$ of the sample $(n=2,875)$.

For the control variables, the mean (median) values of firm size (SIZE) and return on assets $(R O A)$ are 19.570 (19.302) and $0.025(0.034)$, respectively. The ratio of debt to total assets in the sample firms is approximately $44.5 \%$. The sample firms' growth rate $(G R O W T H)$ is about $7.4 \%$ and the mean (median) market-to-book ratio is $1.041(0.731)$. The proportion of equity held by major shareholders is approximately $42 \%$, and the proportion of equity held by foreign investors is about $9.6 \%$ on average. 
Table 2. Descriptive Statistics for Variables

\begin{tabular}{l|c|c|c|c|r|r}
\hline \multicolumn{1}{c|}{ Variables } & $\mathbf{N}$ & Mean & Median & SD & MIN & Max \\
\hline TAXAVOID & 5894 & 0.013 & 0.011 & 0.085 & -0.265 & 0.339 \\
\hline$\triangle D B T A$ & 5894 & 0.001 & 0.000 & 0.161 & -0.556 & 0.534 \\
\hline$\triangle D B O A$ & 5894 & 0.000 & -0.001 & 0.045 & -0.183 & 0.196 \\
\hline COMP_D & 2947 & 0.556 & 1.000 & 0.497 & 0.000 & 1.000 \\
\hline TAXFIN_D & 2875 & 0.386 & 0.000 & 0.487 & 0.000 & 1.000 \\
\hline SIZE & 5894 & 19.570 & 19.302 & 1.475 & 16.851 & 23.725 \\
\hline LEV & 5894 & 0.445 & 0.448 & 0.200 & 0.045 & 0.942 \\
\hline ROA & 5894 & 0.025 & 0.034 & 0.091 & -0.447 & 0.225 \\
\hline CFO & 5894 & 0.053 & 0.049 & 0.088 & -0.220 & 0.325 \\
\hline GROWTH & 5894 & 0.074 & 0.049 & 0.196 & -0.448 & 0.967 \\
\hline MTB & 5894 & 1.041 & 0.731 & 1.004 & 0.096 & 6.341 \\
\hline FOR & 5894 & 0.421 & 0.422 & 0.164 & 0.069 & 0.819 \\
\hline$T A X A V I D$ & 5894 & 0.096 & 0.029 & 0.138 & 0.000 & 0.591 \\
\hline
\end{tabular}

TAXAVOID ${ }_{i, t}$ : Desai and Dharmapala (2006)' $\mathrm{s}$ tax avoidance for firm $i$ in year $t$;

$\triangle D B T A_{i, t}$ : Change in discretionary book-tax accruals;

$\triangle D B O A_{i, t}$ : Change in discretionary book-only accruals;

COMP_D $D_{i, t}$ : Dummy variable that equals 1 if $\triangle D B T A$ is negative and $\triangle D B O A$ is positive, and 0 if $\triangle D B T A$ and $\triangle D B O A$ are both negative;

TAXFIN_ $D_{i, t}$ : Dummy variable that equals 1 if scaled taxable income and leverage ratio in year $\mathrm{t}-1$ are both higher than median value, and 0 if scaled taxable income in year $\mathrm{t}-1$ is higher than the median value but leverage ratio in year $\mathrm{t}-1$ is lower than the median value;

$S I Z E_{i, t}:$ Log of total assets;

$L E V_{i, t}$ : Total liabilities divided by total assets;

$R O A_{i, t}$ : Net income divided by total assets at the beginning of the year;

$C F O_{i, t}$ : Cash flow from operations divided by total assets at the beginning of the year;

$G R O W T H_{i, t}$ : change in sales divided by previous year's sales;

$M T B_{i, t}$ : Market value divided by equity;

$O W N_{i, t}$ : Proportion of ownership held by the largest shareholder of the firms; and

$F O R_{i, t}$ : Proportion of ownership held by foreign investors of the firms.

\subsection{Regression Analysis}

Table 3. Analysis for tax avoidance measure to detect the management of accrual components

\begin{tabular}{|c|c|c|c|c|c|c|}
\hline \multicolumn{7}{|c|}{$\begin{aligned} \text { TAXAVOID }_{i, t}=\beta_{0}+\beta_{1} \triangle D B T A_{i, t}+\beta_{2} \triangle D B O A_{i, t}+\beta_{3} S_{I Z E_{i, t}}+\beta_{4} L E V_{i, t}+\beta_{5} R O A_{i, t}+\beta_{6} C F O_{i, t} \\
\\
+\beta_{7} \text { GROWTH }_{i, t}+\beta_{8} M T B_{i, t}+\beta_{9} O W N_{i, t}+\beta_{10} F O R_{i, t}+\sum Y R+\sum I N D+\varepsilon\end{aligned}$} \\
\hline \multirow{2}{*}{ Variables } & \multicolumn{3}{|c|}{$\triangle D B T A, \triangle D B O A($ Change variables) } & \multicolumn{3}{|c|}{$D B T A, D B O A$ (Level variables) } \\
\hline & Coef. & t-stat & p-value & Coef. & t-stat & p-value \\
\hline Intercept & -0.067 & $-4.49 * * *$ & $<.0001$ & -0.068 & $-4.56 * * *$ & $<.0001$ \\
\hline$\triangle D B T A$ & 0.007 & 1.26 & 0.208 & & & \\
\hline$\triangle D B O A$ & 0.090 & $4.39 * * *$ & $<.0001$ & & & \\
\hline$D B T A$ & & & & -0.010 & 0.01 & 0.270 \\
\hline$D B O A$ & & & & 0.179 & $0.03 * * *$ & $<.0001$ \\
\hline SIZE & 0.003 & $3.97 * * *$ & $<.0001$ & 0.003 & $0.00 * * *$ & $<.0001$ \\
\hline$L E V$ & 0.017 & $3.19 * * *$ & 0.001 & 0.016 & $0.01 * * *$ & 0.002 \\
\hline$R O A$ & 0.230 & $18.35 * * *$ & $<.0001$ & 0.225 & $0.01 * * *$ & $<.0001$ \\
\hline$C F O$ & 0.344 & $29.08 * * *$ & $<.0001$ & 0.343 & $0.01 * * *$ & $<.0001$ \\
\hline GROWTH & 0.100 & $20.16^{* * *}$ & $<.0001$ & 0.100 & $0.00 * * *$ & $<.0001$ \\
\hline$M T B$ & -0.010 & $-10.25 * * *$ & $<.0001$ & -0.010 & $0.00 * * *$ & $<.0001$ \\
\hline$O W N$ & -0.007 & -1.15 & 0.250 & -0.008 & 0.01 & 0.159 \\
\hline FOR & -0.042 & $-5.14 * * *$ & $<.0001$ & -0.042 & $0.01 * * *$ & $<.0001$ \\
\hline$Y R$ & \multicolumn{3}{|c|}{ Included } & \multicolumn{3}{|c|}{ Included } \\
\hline$I N D$ & \multicolumn{3}{|c|}{ Included } & \multicolumn{3}{|c|}{ Included } \\
\hline R2-Adj & \multicolumn{3}{|c|}{0.3665} & \multicolumn{3}{|c|}{0.3698} \\
\hline $\mathrm{N}$ & \multicolumn{3}{|c|}{5894} & \multicolumn{3}{|c|}{5894} \\
\hline
\end{tabular}

Column A of Table 3 presents the results of regression model (1), which tests the association between management of the two accrual components and the tax avoidance proxy. The coefficient of $\triangle D B T A$ is positive, but not 
statistically significant $(t$-statistic $=1.26, p$-value $=0.208)$, implying that the downward adjustment of book-tax accruals for tax reporting purposes is not detected by the tax avoidance proxy. On the other hand, $\triangle D B O A$ is positive and statistically significant $(t$-statistic $=4.39, p$-value $<.0001)$, indicating that the upward adjustment of book-only accruals for financial reporting purposes is captured by the tax avoidance proxy. These results suggest that the proxy cannot completely exclude the possibility of accruals management, and therefore it should be used carefully and only after controlling for the adjustment of book-only accruals, which is not associated with corporate tax planning.

As a sensitivity test, I run the regression with level variables for book-tax and book-only accruals ( $D B T A$ and $D B O A)$ instead of change variables $(\triangle D B T A$ and $\triangle D B O A)$. Column $\mathrm{B}$ of Table 3 shows that the coefficient of $D B T A$ is not statistically significant, but that of $D B O A$ is positively significant, which is consistent with the results of the main regression analysis.

1) $*, * *, * * *$ indicate significance levels at the $10 \%, 5 \%$, and $1 \%$, respectively, based on two-tailed tests.

2) The variables are defined as in Table 2.

Column A of Table 4 presents the results of regression model (2), which tests hypothesis 2 . The coefficient of COMP_D is positive and statistically significant $(t$-statistic $=2.71, p$-value $=0.007)$, implying that tax sheltering activity is better captured by the proxy when firms simultaneously manage both accrual components rather than when firms manage only book-tax accruals. This test provides evidence that the tax avoidance proxy is more useful in settings where firms manage book-only accruals along with book-tax accruals than in settings where firms manage only book-tax accruals for tax planning.

As a sensitivity test, I run regression model (2) with $C O M P_{-} D 1$, an alternative measure of COMP_D.COMP_D1 is a dummy variable that equals 1 if $D B T A$ is lower than its median value and $D B O A$ is higher than its median value, and 0 if $D B T A$ and $D B O A$ are both lower than their respective median values. Column $\mathrm{B}$ of Table 4 reports that the coefficient of COMP_D1 is also positive and statistically significant at $\mathrm{p}<0.001$, which is consistent with the results of the main regression analysis.

Table 4. Analysis for tax avoidance measure to distinguish simultaneous management of book-tax and book-only accruals and management of book-tax accruals alone

$\begin{aligned} \text { TAXAVOID }_{i, t}=\beta_{0}+ & \beta_{1} \text { COMP }_{-} D_{i, t}+\beta_{2} \text { SIZE }_{i, t}+\beta_{3} L E V_{i, t}+\beta_{4} R O A_{i, t}+\beta_{5} C F O_{i, t} \\ & +\beta_{6} G R O W T H_{i, t}+\beta_{7} M T B_{i, t}+\beta_{8} O W N_{i, t}+\beta_{9} F O R_{i, t}+\sum Y R+\sum\end{aligned}$

\begin{tabular}{|c|c|c|c|c|c|c|}
\hline \multirow{2}{*}{ Variables } & \multicolumn{3}{|c|}{ COMP D } & \multicolumn{3}{|c|}{ COMP_D1 } \\
\hline & Coef. & t-stat & p-value & Coef. & t-stat & p-value \\
\hline Intercept & -0.056 & $-2.51 * *$ & 0.012 & -0.046 & $-2.10 * *$ & 0.036 \\
\hline COMP_D & 0.007 & $2.71 * * *$ & 0.007 & & & \\
\hline COMP_D1 & & & & 0.010 & $3.84 * * *$ & 0.000 \\
\hline SIZE & 0.002 & $2.06^{* *}$ & 0.039 & 0.002 & $1.77 *$ & 0.078 \\
\hline$L E V$ & 0.011 & 1.44 & 0.150 & 0.006 & 0.78 & 0.435 \\
\hline$R O A$ & 0.229 & $12.64 * * *$ & $<.0001$ & 0.236 & $12.95 * * *$ & $<.0001$ \\
\hline$C F O$ & 0.329 & $18.71 * * *$ & $<.0001$ & 0.326 & $18.57 * * *$ & $<.0001$ \\
\hline GROWTH & 0.103 & $14.29 * * *$ & $<.0001$ & 0.114 & $16.03 * * *$ & $<.0001$ \\
\hline$M T B$ & -0.010 & $-7.12 * * *$ & $<.0001$ & -0.009 & $-6.37 * * *$ & $<.0001$ \\
\hline$O W N$ & -0.007 & -0.86 & 0.392 & -0.012 & -1.38 & 0.168 \\
\hline FOR & -0.039 & $-3.26 * * *$ & 0.001 & -0.041 & $-3.46 * * *$ & 0.001 \\
\hline$Y R$ & \multicolumn{3}{|c|}{ Comprised } & \multicolumn{3}{|c|}{ Included } \\
\hline$I N D$ & \multicolumn{3}{|c|}{ Included } & \multicolumn{3}{|c|}{ Included } \\
\hline R2-Adj & \multicolumn{3}{|c|}{0.3578} & \multicolumn{3}{|c|}{0.3828} \\
\hline $\mathrm{N}$ & \multicolumn{3}{|c|}{2947} & \multicolumn{3}{|c|}{2884} \\
\hline
\end{tabular}

1) $*, * *, * * *$ indicate significance levels at the $10 \%, 5 \%$, and $1 \%$, respectively, based on two-tailed tests.

2) $C O M P D 1_{i, t}$ : Dummy variable that equals 1 if $D B T A$ is lower than its median value and $D B O A$ is higher than its median value, and 0 if $D B T A$ and $D B \bar{O} A$ both are lower than their respective median values. The other variables are defined as in Table 2 . 
Table 5 presents the results of regression model (3), which tests hypothesis 3 . The results show that the coefficient of TAXFIN_D is positive and statistically significant $(t$-statistic $=4.15, p$-value $<.0001)$, which implies that the value of the tax avoidance proxy is higher for firms with both high tax costs and high financial reporting costs than for firms with high tax costs, but low financial reporting costs. This result can be interpreted as follows: the proxy is more powerful in detecting tax avoidance activity in a sample of firms with incentives to manage both accrual components simultaneously than in firms with incentives to manage only book-tax accruals.

Panel B of Table 5 reveals the results of regression (2) with TAXFIN_D1, an alternative measure of TAXFIN_D. TAXFIN_D1 is a dummy variable that equals 1 if the scaled taxable income and debt ratio in the year $t-1$ are both higher than their respective mean values, and 0 if the scaled taxable income in year $t-1$ is higher, but the debt ratio in year $t-1$ is lower than their respective mean values. The coefficient of TAXFIN_D1 is also positive and statistically significant $(t$-statistic $=3.53, p$-value $=0.000)$, thus supporting hypothesis 3 .

Table 5. The level of tax avoidance depending on firms' financial reporting costs when tax costs is high

\begin{tabular}{|c|c|c|c|c|c|c|}
\hline \multirow{2}{*}{ Variables } & \multicolumn{3}{|c|}{$T A X F I N D$} & \multicolumn{3}{|c|}{$T A X F I N \_D 1$} \\
\hline & Coef. & t-stat & p-value & Coef. & t-stat & p-value \\
\hline Intercept & -0.119 & $-5.46 * * *$ & $<.0001$ & -0.104 & $-4.91 * * *$ & $<.0001$ \\
\hline TAXFIN_D & 0.016 & $4.15^{* * *}$ & $<.0001$ & & & \\
\hline TAXFIN_D1 & & & & 0.013 & $3.53 * * *$ & 0.000 \\
\hline SIZE & 0.007 & $6.01 * * *$ & $<.0001$ & 0.006 & $5.35 * * *$ & $<.0001$ \\
\hline$L E V$ & -0.055 & $-4.62 * * *$ & $<.0001$ & -0.048 & $-4.16 * * *$ & $<.0001$ \\
\hline$R O A$ & 0.069 & $2.85 * * *$ & 0.005 & 0.083 & $3.42 * * *$ & 0.001 \\
\hline$C F O$ & 0.322 & $18.94 * * *$ & $<.0001$ & 0.302 & $18.40 * * *$ & $<.0001$ \\
\hline GROWTH & 0.114 & $15.08 * * *$ & $<.0001$ & 0.109 & $14.82 * * *$ & $<.0001$ \\
\hline$M T B$ & -0.012 & $-8.31 * * *$ & $<.0001$ & -0.011 & $-7.53 * * *$ & $<.0001$ \\
\hline$O W N$ & -0.009 & -1.01 & 0.313 & -0.003 & -0.33 & 0.743 \\
\hline FOR & -0.028 & $-2.58 * *$ & 0.010 & -0.024 & $-2.36 * *$ & 0.018 \\
\hline$Y R$ & \multicolumn{3}{|c|}{ Included } & \multicolumn{3}{|c|}{ Included } \\
\hline$I N D$ & \multicolumn{3}{|c|}{ Included } & \multicolumn{3}{|c|}{ Included } \\
\hline R2-Adj & \multicolumn{3}{|c|}{0.2848} & \multicolumn{3}{|c|}{0.3024} \\
\hline $\mathrm{N}$ & \multicolumn{3}{|c|}{2873} & \multicolumn{3}{|c|}{2588} \\
\hline
\end{tabular}

1) $*, * *, * * *$ indicate significance levels at the $10 \%, 5 \%$, and $1 \%$, respectively, based on two-tailed tests.

2) TAXFIN_ $D_{i, t}$ : Dummy variable that equals 1 if scaled taxable income and leverage ratio in year t-1 are both higher than mean value, and 0 if scaled taxable income in year $\mathrm{t}-1$ is higher than the mean value but leverage ratio in year $\mathrm{t}-1$ is lower than the mean value. The other variables are defined as in Table 2 .

\section{CONCLUSION}

Desai and Dharmapala (2006) propose a tax avoidance proxy estimated by the residual of the book-tax difference that is not captured by total accruals based on the assumption that the book-tax difference is attributable to tax avoidance and earnings management. However, Korea-based studies present mixed results as to whether the booktax difference reflects tax avoidance because in Korea, firms commonly attempt to avoid taxes using accruals with high tax conformity. Downward management of book-tax accruals leads to a decrease not only in taxable income, but also in book income, which does not result in a book-tax gap. Therefore, it is intuitive that for firms engaging in tax avoidance activity, when no book-tax gap is generated, the tax avoidance proxy fails to detect this activity. In addition, firms concerned about lower book income due to downward management of book-tax accruals may be inclined to compensate for reduced book income by upward managing book-only accruals while maintaining the same level of taxable income. It is an empirical question as to whether management of book-only accruals is captured by the tax avoidance proxy because it increases the book-tax difference; however, the tax avoidance proxy is developed to exclude the effect of earnings management via total accruals. In this empirical study, I verify the ability of the proxy developed by Desai and Dharmapala (2006) to detect firms' management of book-tax and bookonly accruals. I test my hypotheses by analyzing archival data on publicly-listed Korean firms during the period from 2000 to 2013.

The results of this study show that the tax avoidance proxy does not detect downward management of book-tax accruals, as expected earlier. In addition, the proxy is positively related to upward management of book-only 
accruals, implying that it cannot exclude the effect of earnings management via book-only accruals. I also find that the proxy better detects simultaneous management of both accrual components than management of book-tax accruals alone. Further, I find that firms with high tax and financial reporting costs show higher level of tax avoidance proxy than firms with high tax costs and low financial reporting costs. These results imply that the proxy can still be effective in measuring tax avoidance in firms that have concerns about increased financial reporting costs due to tax avoidance in settings where accounting-tax alignment is relatively high and aggressive tax shelters are restricted.

This study provides guidance to researchers that the tax avoidance proxy should be employed with caution and in the appropriate setting. The proxy is not suitable for evaluation of firms that tend to avoid taxes without generating a book-tax gap or for nations where such tax avoidance activities are pervasive. Therefore, the proxy can be a good indicator only when used for firms that are conscious of their financial reporting costs and have incentive to manage both taxable income and book income at the same time. Moreover, this study suggests that it is advisable to control for earnings management through book-only accruals when using the tax avoidance proxy. This paper suggests the need to develop a new measure or elaborate on the existing tax avoidance measure so that it embraces management of items that do not affect the amount of book-tax difference because many firms worldwide commonly avoid taxes in ways unlike U.S. firms, where the tax avoidance proxy is most applicable.

\section{ACKNOWLEDGMENTS}

This research was supported by the Gachon University research fund of 2015 (GCU-2015-0051).

\section{AUTHOR BIOGRAPHY}

Hyun-Ah Lee is an Assistant Professor at the Gachon University (2015-Present), A member of Korean Institute of Certified Public Accountants (2002-Present)

\section{REFERENCE}

Calegari, M. (2000). The effect of tax accounting rules on capital structure and discretionary accruals. Journal of Accounting and Economics, 30(1) 1-31.

Choi, W. W., Lee, H. A., and Jun, B. W. (2009). The provision of tax services by incumbent auditors and earnings management: Evidence from Korea. Journal of International Financial Management and Accounting, 20(2) 79-103.

Choi, W. W. and Lee, H. A. (2013). Management of accrual components in response to corporate income tax rate changes: Evidence from Korea. Journal of Applied Business Research, 29(5) 1421-1436.

Desai, M. and Dharmapala, D. (2006). Corporate tax avoidance and high-powered incentives. Journal of Financial Economics, 79(1) 145-179.

Hanlon, M. (2005). The persistence and pricing of earnings, accruals and cash flows when firms have large book-tax difference. The Accounting Review, 80(1) 831-863.

Lev, B. and Nissim, D. (2004). Taxable income, future earnings, and equity values. The Accounting Review, 79(4) 1039-1074.

Manzon, G. and Plesko, G. (2002). The relation between financial and tax reporting measures of income. Tax Law Review, 55(2) 175-214.

Mills, L. (1998). Book-tax differences and Internal Revenue Service adjustments. Journal of Accounting Research, 36(2) 343356.

Tang, T. and Firth, M. (2011). Can book-tax differences capture earnings management and tax management?: Empirical evidence from China. The International Journal of Accounting, 46(2) 175-204.

Jenkins, N. and Pincus, M. (1998). LIFO versus FIFO: updating what we have learned. Working paper, University of Iowa, Iowa City, September 1998.

Shim, C., Kim, M. and Lee, J. (2006). The relation between book-tax difference and tax investigation. Korean Tax Review, 17(4) 43-79.

Guenther, D. A. (1994). Earnings management in response to corporate tax rate changes: Evidence from the 1986 Tax Reform Act. The Accounting Review, 69(1) 230-243.

Desai, M. A. (2003). The divergence between book and tax income. Tax Policy and the Economy, 17(1) 169-206.

Choi, H. S. (2012). An empirical study on tax avoidance and book-tax differences. Korea International Accounting Review, 45(1) 195-218.

Scholes, M. S. and Wolfson, M. A. (1992). Taxes and Business Strategy: A Planning Approach. Edgewood Cliffs, NJ: Prentice Hall. 
Phillips, J., Pincus, M., and Rego, S. O. (2003). Earnings management: New evidence based on deferred tax expense. The Accounting Review, 78(2) 491-521.

Watts, R. and Zimmerman, J. (1986). Positive Accounting Theory. Edgewood Cliffs, NJ: Prentice Hall.

Sweeney A. P (1994). Debt covenant violations and managers' accounting responses. Journal of Accounting and Economics, 17(3) 281-308. 